\title{
Mysticism AND Mental HeAlth: A CRITICAl Dialogue
}

\author{
Authors: \\ George Drazenovich ${ }^{1}$ \\ Celia Kourie $^{2}$

\section{Affiliations: Canada} \\ ${ }^{1}$ Lakehead University, \\ ${ }^{2}$ Department of Christian \\ Spirituality, Church \\ History and Missiology, \\ University of South Africa, \\ South Africa
}

\section{Correspondence to:}

Celia Kourie

email:

kouricet@unisa.ac.za

\section{Postal address:}

Department of Christian

Spirituality, Church

History and Missiology,

School of Social Sciences

and Theology, College of

Humanities, Unisa,

PO Box 392, Pretoria 0003

South Africa

\section{Keywords:}

consciousness; mysticism; neuropsychiatry; psychosis; spirituality

\section{Dates:}

Received: 08 Jan. 2009

Accepted: 12 Apr. 2010

Published: 01 Sept. 2010

How to cite this article: Drazenovich, G. \& Kourie, C., 2010, 'Mysticism and mental health: A critical dialogue', HTS Teologiese Studies/Theological Studies 66(2), Art. \#845, 8 pages.

DOI: $10.4102 /$ hts.v66i2.845

This article is available at:

http://www.hts.org.za

\section{Note:}

This article is a reworked version of a section of George Drazenovich's MTh dissertation, 'An exploration of the value of spirituality in the field of mental health', submitted to, and accepted by, the University of South Africa in 2007, with Prof. Dr Celia Kourie as supervisor.

\section{(C) 2010. The Authors.} Licensee: OpenJournals Publishing. This work is licensed under the Creative Commons Attribution License.

\section{ABSTRACT}

Contemporary research suggests that a path is now open for critical dialogue between mysticism and mental health. Data are accumulating regarding the frequency with which mystical experience occurs in the general population. Social science researchers are undertaking studies to determine whether people can knowledgably differentiate between the presence of a mystical experience and other types of experience that occur in their lives. Psychologists are developing clinical criteria by which the mystical and psychotic experience can be differentiated. Neuropsychiatric researchers are exploring the effect of the mystical experience by way of enhanced brain imagery. Theologians are opening up the received wisdom of the mystical tradition and applying it to the present historical context. This paper drew these diverse disciplines together to demonstrate an emerging consensus with respect to the efficacy of mysticism in the field of mental health.

\section{INTRODUCTION}

In 1998, the World Health's Organization's (WHO) 'WHOQOL and Spirituality, Religiousness and Personal Beliefs: Report on WHO Consultation' stated:

Until recently the health professions have largely followed a medical model, which seeks to treat patients by focusing on medicines and surgery, and gives less importance to beliefs and to faith - in healing, in the physician and in the doctor-patient relationship. This reductionism or mechanistic view of patients as being only a material body is no longer satisfactory. Patients and physicians have begun to realize the value of elements such as faith, hope and compassion in the healing process. The value of such 'spiritual' elements in health and quality of life has led to research in this field in an attempt to move towards a more holistic view of health that includes a non-material dimension (emphasizing the seamless connections between mind and body).

(WHO 1998:7)

A fundamental aspect of our human experience includes striving for meaning, hopefulness and purpose - this process can be understood as a spiritual experience. Another aspect of shared human experience includes the experience of psychological distress and alienation from oneself and the community, which can be understood as mental illness. Spirituality, as an integral component of human experience, involves tapping into a person's innate need for integration while paving the way forward towards a transformative experience - sometimes rendered in traditional Christian theological vocabulary as 'salvation'. Each experience carries with it its own history and language. The transformative experience, for example, has been described as mystical. To avoid ambiguity with respect to what is meant by a mystical experience, researchers have studied whether people can knowledgably identify, through structured questionnaires that describe acknowledged psychological dynamics associated with mystical experience, if they have ever had one. Additionally, psychologists and psychiatrists have explored clinical criteria by which the mystical and psychotic experience can be differentiated. These criteria assist with facilitating the growth potential of the mystical experience. Authentic mystical experience has historically been able to unify the deep structures of exteriority and interiority, otherness and sameness, the Divine and the human. Lukoff (1985:155) observes that psychotic and mystical experiences have been associated since earliest recorded history and, undoubtedly, before. It is ironic that the pre-modern intuition that madness and creativity are linked, is again being explored, as we plunge ever deeper into the biological and neurological composition of the human person and begin to appreciate in richer ways the mystery that such knowledge reveals. The specific experience of mysticism as it related to mental health, is the focus of the present research.

\section{FREQUENCY OF MYSTICAL EXPERIENCE}

Hood and Morris (1981:82) note that the frequency of mystical experience and the commonality of the description are consistent themes running through more popular treatments of mysticism. The foregoing has caught both social scientists and religious leaders by surprise, albeit for different reasons. For their part, religious leaders generally circumscribe the mystical experience within a relatively narrow range of religious experiences, with Christian leaders historically, having expressed some reticence concerning claims of mystical experience. Aside from the understandable concern that some experiences may be self-delusion at best, or a form of uncritical superstition at worst, issues of authority arise. As Allen (1999:29) writes, official Catholicism has always taken a cautious, even oppositional, stance toward mystical experience and claims of direct, divine inspiration - especially in cases where mystics have insisted that what they learned in their private revelations supersedes Church law and authority. From the domain of social science, Prince (1979:68) notes that, up until a few years ago, we had very little idea of the frequency of mystical experience. Ever since Freud's work, The Future of an Illusion (1927), in which he analysed the religious or mystical impulse as being the universal compulsive neurosis of mankind, rooted in narcissistic needs, attachments and wish fulfillments, many segments of the mental health professions have had, at best, an ambivalent attitude towards the mystical impulse of the human person. That has changed as mysticism and religious experience has become more rigorously studied. Prince (1979:86) observes that of three surveys done separately, each reported that some $20 \%-40 \%$ of the 
population claimed mystical or religious experience. Similarly, Hood and Morris (1981:76) note that studies of mysticism are consistent in finding that approximately one-third of persons sampled affirm that they have had a mystical experience. This figure holds true whether data are obtained from survey research in the United States of America or the United Kingdom. Studies include: Bourque and Back $(1968,1971)$, Greeley (1974), Hay and Morrisy (1978), Thomas and Cooper $(1978,1980)$ and Wuthnow (1978). Sampling from volunteer population yields similar results. These include Brown, Spilka and Cassidy (1978), Hood (1973a, 1973b, 1975, 1977a, 1977b, 1978), Hood and Hall (1980) and Margolis and Elifson (1979).

In addition to the frequency of mystical reports, research also demonstrates that there is a psychodynamic context in which people can make judgments with respect to mystical experience. Contrary to other studies suggesting that the mystical experience is so ambiguous that it cannot be measured by structured questionnaires (e.g. Thomas \& Cooper 1977, 1980), Hood and Morris's (1981:79) research indicates that persons can knowledgably apply mystical criteria to their own experiences. They conclude that not only is mysticism relatively common, but it is knowledge-based. In other words, people are aware that they are having an existential experience of the transcendent that can be contrasted from other types of life experiences. Hood and Morris (1981:82) conclude that 'persons do not indiscriminately identify themselves as having had a mystical experience; hence, confrontation with such common experiences appears a task for more serious consideration'. Such consideration is occurring among psychologists who are developing criteria by which the mystical experience and the psychotic can be differentiated.

\section{DIFFERENTIATING MYSTICISM AND PSYCHOSIS}

Not all self-reports of ecstatic divine union indicate that the person is having a mystical experience. The similarity between psychotic symptoms and aspects of mystical experiences has received acknowledgement and discussion in mental health literature (Arieti 1976; Buckley 1981; James 1961). Buckley (1981) writes:

Though the correspondence between the comparatively benign mystical experience and the onset of acute psychosis is a limited one, sufficient overlap exists to warrant systematic biological and psychological investigation of such altered state experiences in the hope of illuminating further the nature of both.

(Buckley 1981:521)

While both psychosis and mysticism lead to perceptual changes, the effects of each change are distinct. Unlike the mystical experience, in which the perceptual change leads to greater integration, in psychosis, the perceptual change in experience leads to increasing fragmentation and confusion. In this regard, Clarke (1998) writes:

In psychosis (and drug experiences that go wrong, or shade into psychosis), the orderly return does not happen. The individual finds themselves [sic] stranded beyond the reach of their constructs or propositional subsystem, trying to operate in the world. Not surprisingly this is extraordinarily difficult. The familiar boundaries between people, events, time and space are not accessible as before. Telepathy seems normal. Other people can read, and worse, interfere with, the individual's thoughts. Coincidences abound - everything is connected and everything is disconnected. Everything is possible and nothing is possible. Where this new reality might be exhilarating for a short while, the sustained experience is terrifying. The desperate sufferer tries to make sense of the unfamiliar environment, clutching at whatever connections come to hand. In this way delusions, which usually have their origin in the early stage of the breakdown, are born. In another dissolution of normal boundaries, internal concerns are experienced as external communication, and the person hears voices. Normal thought is disrupted - or as the psychiatrist would say, disordered.

(Clarke 1998:1)
Additionally, other phenomena that may occur in acute psychotic states, such as self-destructive acts and aggressive and sexual outbursts, are not part of the mystical experience, though the latter have been observed in some states of 'possession' (Buckley 1981:521). Another noticeable difference between the psychotic and mystical experience is the experience of terror and fear. It was observed that people with schizophrenia who reported mystical experience, also reported a significantly higher incidence of terror and fear. These results are notable because scholars such as Hood (1975) do not include these emotions as characteristic of mystical states. Those who do include these emotions in their description of mystical states, however, often speak of a developmental process in which these negative emotional states are eventually extinguished (Siglag 1986:134). Siglag hypothesised that terror and fear are, therefore, related to schizoaffective disturbances. To test his hypothesis that one could clinically distinguish between schizoaffective and schizophrenic experiences and mystical ones, Siglag (1986) conducted research on a group of 75 adults who were experiencing schizophrenia. The study was intended to address specific questions about the relationship between schizophrenic and mystical states.

Siglag (1986:130) found that individuals who experienced a mystical state are more likely to see a sense of oneness and unity within the world. They are also more likely to see their experience as valid and meaningful. One of the objectives of Siglag's study was to determine whether those people experiencing schizophrenia, who claim that they have undergone a mystical experience, differ from those who do not make such a claim.

Many researchers have observed that both schizophrenic and mystical states reflect the manner in which individuals respond to extreme stress or the need to reorganise their lives (Boisen 1936; Laing 1967; Karon \& Vandenbos 1981). The mystical experience offers coherence, clarity and peace; this is in contrast to the schizophrenic experience, which produces further confusion and disintegration. Siglag found that individuals with schizophrenia who had a mystical experience were more likely to have experienced a sense of unity, oneness or connectedness with the world, than those who had not undergone a mystical experience. They were also more likely to report a range of affective experiences and have experienced joyful, peaceful states of consciousness, as well as a sense of sacredness and holiness. Finally, they were more likely to see their experience as valid and meaningful, than other individuals with schizophrenia (Siglag 1986:138).

Siglag's (1986:137) research found that the mystical experience questionnaire used in his research showed sensitivity in distinguishing qualities of schizophrenic states that are similar to mystical states and highlighting types of experiences that are central for schizophrenic states but not for mystical states. This is important since we now have appropriate tools for measuring the characteristics of mystical states and can thus assess the difference between mystical and other states of consciousness.

By clearly understanding the nature of the mystical experience, mental health professionals are now in a better position to distinguish mystical experiences from psychotic ones. This differentiation allows mental health practitioners to appreciate the integration that can be facilitated by a mystical approach. The mystical approach has a long and sustained history. Jaspers (1963:806) notes that the greatest successes in mental health have not belonged to psychiatrists but to shamans, priests, leaders of sects, wonder-workers, confessors and spiritual guides of earlier times.

The 'exercitia spiritualia' of Ignatius Loyola were enormously successful and provide us with examples of real psychic cure; they were aimed at the control, arbitrary production and repression of every kind of emotion, affect or thought. Yoga techniques and the meditative exercises of Buddhism are also extraordinarily effective. (Jaspers 1963:805) 
Some analysis of the mystical approaches utilised in the facilitation of human integration and existential meaning is therefore beneficial. There are two distinct approaches in the Christian mystical tradition. These approaches are distinguished by the terms 'apophatic' and 'kataphatic'. A description of these terms based on a representative sample of each approach will be described below. The apophatic approach has been dominant among mystics in the Church, particularly in the medieval period with Ignatius of Loyola (d. $1555 \mathrm{CE}$ ) being a notable exception. Ignatian spirituality, given its kataphatic character, is an activist type of spirituality.

\section{Kataphatic mysticism - Ignatius of Loyola}

Ignatius of Loyola's work, Spiritual exercises ${ }^{1}$, is the fruit of his spiritual journey to maturity. In the Exercises, Ignatius's personal insights into spirituality find their clearest expression (Gleason 1989:17). The genesis of the Spiritual exercises is drawn from the well of Ignatius's own mystical experience. After finally recovering in Montserrat from wounds he had received in battle, Ignatius had a conversion experience and discerned that he needed to change his life direction.

From Montserrat in $1522 \mathrm{CE}$, Ignatius journeyed toward Barcelona but stopped along the Cardoner River at a town called Manresa. Intending to stay only a few days, he remained there for ten months. O'Neal (1993) writes that Ignatius had a vision on the banks of this river, which he regarded as the most significant in his life:

The vision was more of an enlightenment about which he later said that he learned more on that one occasion than he did in the rest of his life ... Ignatius never revealed exactly what the vision was, but it seems to have been an encounter with God as He really is so that all creation was seen in a new light and acquired a new meaning and relevance, an experience that enabled Ignatius to find God in all things. This grace, finding God in all things, is one of the central characteristics of (Ignatian) spirituality.

(O'Neal 1993:3-4)

From these and other experiences, Ignatius gradually developed a systematic method of sharing with others his insight into the mystical life. This method became Ignatius's magnum opus, the Spiritual exercises. The Exercises are unique in the history of Christian mysticism in that they are simultaneously deeply experiential, but also systematic and structured.

The transference of his previous life context, which was militaristic and feudal, to a mystical one brought with it a creative use of imagery. Images associated with battle (e.g. the 'two standards'), ${ }^{2}$ chivalry as well as feudal theological images (e.g. imagining oneself in the heavenly court, before the divine Majesty, etc.), figure prominently. Ignatius uses secular images from his own historical, social and cultural context to point to spiritual realities. Many of the images are dated. Consequently, some appreciation of the historical context of his choice of symbols is important in order to appreciate his insights. Most spiritual directors using the Exercises use more contemporary symbols that are analogous to Ignatius's medieval imagery. Symbols ought to be readily recognisable and resonate with our contemporary mind in order to have the desired effect and achieve the purpose for which the Exercises were designed.

Ignatius begins the Exercises by writing that its purpose is to help the exercitant conquer the self and to regulate one's life so as not to be influenced by any inordinate attachment (Gleason 1989:48). This freedom facilitates the understanding of one's

1.Exercitia spiritualia, written between 1522 and 1524 was first published in 1548 (see Fleming 1978).

2.The two standards is an exercise in which the exercitants imagine themselves in a a 1 che so as to withstand the demons who are sent from the other standard (Gleason 1989:75). destiny and assists in providing the courage to carry it out. In psychodynamic vocabulary, destiny is an unconscious aspiration that a person intuitively feels will be realised. Psychological crisis or existential angst is often an unconscious desire to break free of one's fate; the opposite of destiny. According to Freud, fate is that which sets one's personality on course. It can become the tragic element in one's character. It is, in Jungian vocabulary, the shadow side of the unconscious. While both destiny and fate are internal and part of the unconscious, they are quite distinct. Indeed, in Freudian terms, conflictual patterns within one's unconscious are often various libidinous 'ids' (or drives) vying for domination of the ego. The ego is the ' $I$ ' that must reconcile all of these parts in a harmonious unity. Harmony and a general psychic élan ensue as a consequence of activity springing from destiny, while dysfunctional neuroticism and hyper-anxiety spring from the ego's surrender to fate.

For Ignatius, reflection on one's life context is a critical component in breaking free of fate in order to live out of destiny. Ignatius believes that one's destiny is discovered in the call of Christ the King. This call is discerned in the second week of the Exercises. Once found, a person will begin to fashion daily life according to one's destiny, which lies deep within one's unconscious and presents itself in a variety of ways. Our task in discerning our destiny is to interpret the action of the good and bad spirit.

Ignatius describes destiny as a battlefield on which our soul (the ' $\mathrm{I}$ ') is engaged in a struggle. There are shadow forces (bad spirits) frustrating the integration of our destiny within ourselves. Drawing on classic Christian vocabulary, Ignatius refers to these shadow forces as the devil or Lucifer. In the original translated text of the Exercises, Ignatius refers to Lucifer symbolically as the 'enemy of our human nature' (Gleason 1989:75). May (1969:139) notes that the devil comes from the Greek word diabolis, which literally means 'to tear apart' (dia-bollein). In a passage ('The two standards') that can easily be interpreted as the libidinous id seeking to dominate the ego, Ignatius writes:

'The ... point' is to listen to the harangue which he [the devil] delivers to them, how he spurs them on to ensnare men [sic] and to bind them in chains. He bids them first to tempt people with the lust of riches [as he is most accustomed to do], that they may thereby more easily gain the empty honor of the world, and then come to unbounded pride. The first step in his snare is that of riches, the second honor, the third pride. From these three steps Satan leads on to all other vices.

(cited in Gleason 1989:76)

To counter these ids, the superego (Christ consciousness) presents another alternative to the ego. Christ is offered symbolically as that which will hold the ' $I$ ' together. May (1969:139) notes that the term 'symbolic' is the antonym to 'diabolic'. Symbolic comes from sym-bollein and means 'to throw together'.

'The ... point' is to listen to the discourse which Christ our Lord makes to all His servants and friends whom He sends on this mission, charging them that they should seek to help all men; first by encouraging them to embrace the most perfect spiritual poverty, and if it should please His Divine Majesty, to choose them for it, also to embrace actual poverty. Secondly, by encouraging them to desire insults and contempt, for from these two things come humility. So then there are three steps: the first, poverty opposed to riches; the second scorn or contempt, opposed to worldly honor, the third humility, opposed to pride. From these three steps let them lead all people to all virtues.

(cited in Gleason 1989:76)

For Ignatius, one of the ways for the realisation of destiny to occur is to pay attention to the symbolic nature of dreams and images that occur in different states of consciousness. Paying attention, in a critical manner, to details of visions and images is an important dimension of the kataphatic approach. Nowhere is this more evident than in the Ignatian method of 'composition of place'. 
'Composition of place' is related to the kataphatic method and refers to the method that the exercitant is asked to practice when meditating on particular texts. Ignatius suggests, in the first preludes to the Exercises, which are often meditations on Biblical scenes, that the exercitant create a mental image of the place. Ignatius writes:

It should be noted at this point that when the meditation or contemplation is on a visible object, for example, contemplating Christ our Lord during His life on earth, the image will consist of seeing with the mind's eye the physical place where the object we wish to contemplate is present.

(cited in Gleason 1989:54)

Ignatius has an intuition into the importance of conscious images and their effect on the unconscious. Conscious images can direct deep unconscious stirrings. As attention is paid to the development of conscious images and symbols in the kataphatic approach, these images, in turn, name and direct unconscious movements.

Unlike kataphatic mysticism, apophatic mysticism eschews subjective images, desires and dreams, deliberately suspending conscious reflection on them. It is useful to turn to one of the most prominent of the apophatic mystics, Meister Eckhart (d. $1328 \mathrm{CE}$ ), to explore how this approach has been interpreted historically in the Christian tradition.

\section{Apophatic mysticism - Meister Eckhart}

Meister Eckhart is known as the father of German mysticism and is deemed the greatest of all mystics. Several authors refer to him with honour as 'the man from whom God hid nothing' (Brown 2005; McGinn 2003; O'Neal 1996). He is known as a philosopher and a theologian, but it was as a mystic that Eckhart excelled In his day, Eckhart enjoyed success as a popular preacher and churchman of high rank in his order, the Dominicans. However Eckhart was the one of the most prominent theologians of the medieval period to be formally charged with heresy. The shock of his trial for heresy and the condemnation of some of his work by Pope John XXII (d. 1334 CE) in Agro Dominco (1329) cast a shadow over his reputation and a lingering suspicion over his orthodoxy that has lasted to this day. ${ }^{3}$ Ratzinger (1989) in a Letter to the bishops of the Catholic Church on some aspects of Christian meditation referenced Meister Eckhart and wrote:

Still others do not hesitate to place that absolute without images or concepts, which is proper to Buddhist theory, on the same level as the majesty of God revealed in Christ, which towers above finite reality ... Thus they propose abandoning not only meditation on the salvific works accomplished in history by the God of the Old and New Covenant, but also the very idea of the One and Triune God, who is Love, in favour of an immersion in the indeterminate abyss of the divinity.

(Ratzinger 1989:12)

Interior renewal and the indwelling of God were key elements in Eckhart's mysticism. According to Eckhart, Christ became a child of a human being in order that we might become children of God. Eckhart states, 'Why did God become man? So that I might be born of the same God' (cited in Fox 2000:356).

To enter into the apophatic experience, a certain degree of asceticism is necessary. Like all of Eckhart's spirituality, asceticism is not understood as an external practice, but, rather as primarily psychodynamic. Indeed, Eckhart's resistance to, and perhaps even rejection of, the idea that exterior penance

3.Since 1980, the Dominican Order and the International Eckhart Society have tried to obtain an official declaration from the papacy to acknowledge 'the exemplary character of Eckhart's activity and preaching' and to recommend his writing as an expression of authentic Christian mysticism. To date, no such statement has appeared, although Pope John Paul II quoted Eckhart with approval in an address in 1987. In 1992, the then Master of the Dominican Order, Timothy Radcliffe, noted that the Order had tried to have the censure on Eckhart lifted and was told that there was really no need since he was never condemned persolly, only some propositions really no nupes free to say that he is a good and orthodox theologian (Mills 2003:63) leads towards union with God is outlined clearly in the Talks of instructions (c.1290):

Many people think that they are performing great works by outward things such as fasting, going barefoot, or other such things which are called penance. But the true and best penance is that whereby one improves greatly and in the highest degree; and that is that a person should experience a complete and perfect turning away from whatever is not entirely God and divine in themselves and in all creatures, and have a full, perfect and complete turning towards their beloved God in unshakeable love, so that their devotion and yearning for Him are great.

(cited in McGinn \& Colledge 1981:33-34)

Central to Eckhart's ascesis is detachment, which is a central component in the apophatic approach. Detachment is a wellwinnowed term and popularised in recent times by the interest in Eastern religions. Eckhart, articulating a fairly common Buddhist theme, writes,

all suffering comes from love and attachment. So if I suffer on account of transitory things, then I and my heart have love and attachment for temporal things, I do not love God with all my heart and do not yet love that which God wishes me to love with Him.

(Woods 2005:19)

Detachment, or as Eckhart described it in the vernacular German of his day - abegescheidenheit, is an integral aspect of apophatic spirituality. It forms the praxis of apophatic mysticism and speaks in a practical way to appropriate psychodynamic disposition. Schurmann (2001:81-82) examines the etymology of the term abegescheidenheit, in order to better understand its meaning. Abegescheidenheit (in modern German Abgeschiedenheit) is formed of the prefix $a b$-, which designates a separation ${ }^{4}$ and the verb scheiden or gescheiden. In its transitive form, this verb means 'to isolate', 'to split', 'to separate' and, in its intransitive form, 'to depart,' 'to die'. The word abegescheidenheit evokes, in the illusive thought of Meister Eckhart, a mind that is on the way to dispossession from all exteriority which might spoil its serenity. The difficulty in interpreting Meister Eckhart stems from the necessity of reproducing in ourselves the disposition that allows such an encounter to occur. Some analysis of the notion of detachment, therefore, is helpful in order to understand the apophatic approach.

\section{Detachment (Abegescheidenheit)}

Eckhart did not develop any specific techniques to facilitate detachment. As Lancaster (2001:41) writes, Eckhart eschews technical practices warning that whoever seeks God with a special technique gets the technique but misses God, who lies hidden in it. Eckhart's writings are invariably directed to the ends and not the means. As Merton (1989:54) notes, Eckhart did not have the kind of mind that wasted time being cautious about every comma: he trusted people to recognise that what he saw was worth seeing because it brought obvious fruits of life and joy. The peace that detachment offers is the peace that comes from taking every moment without expectation, anxiety or promise (Stephens 2005:36). Eckhart states:

Every attachment to every work deprives one of the freedom to wait upon God in the present and to follow him alone in the light with which he would guide you in what to do and what to leave alone, free and renewed in every present moment, as if this were all that you had ever had or wanted or could do. Every attachment or every work you propose deprives you again and again of this freedom.

(cited in McGinn \& Colledge 1981:178)

Abegescheidenheit becomes key in terms of receptivity of the Divine truth and becoming one with God (unitas indistinctionis). Eckhart's abegescheidenheit is a 'cutting away' or 'letting go' of things. (McGinn 2000:4). A somewhat more contemporary understanding of Eckhart's understanding can be found in the expression of Thoreau (1985):

I went to the woods because I wished to live deliberately, to front only the essential facts of life, and see if I could not learn what it 
had to teach, and not, when I came to die discover that I had not lived. I did not wish to live what was not life, living is so dear ... I wanted to live deep and suck out all the marrow of life, to cut a broad swath and shave close ...

(Thoreau 1985:75)

Eckhart frames abegescheidenheit in two ways (biblical and philosophical) - both of which speak to the same psychodynamic reality. Schurmann (2001) writes:

Detachment has been described as a passive attitude: the receptive intellect and virginity - one a philosophical figure of thought, the other biblical - both speak of the absence of any determination of the mind.

(Schurmann 2001:18)

Such a passive disposition does not lead to withdrawal, quietism or resignation. On the contrary, it forms a pointe vierge for action. For medieval women and monastics, virginity, properly understood, had less to do with physicality than it did with interior disposition. The narrow sexual resonances that we associate with the concept of virginity in our modern era spring, as Dworkin writes,

from a male frame of reference which sees virginity as a state of passive waiting or vulnerability; it precedes and is antithetical to wholeness. But in the women's frame, virginity is a fuller experience of selfhood and identity. In the male frame, virginity is virtually synonymous with ignorance; in the woman's frame, it is recovery of the capacity to know by direct experience of the world.

(cited in Norris 1996:200)

It is in this positive, spirit-affirming perspective that Eckhart speaks of the 'negative' concept of abegescheidenheit. Eckhart's feminine conceptions and practical applications of his spirituality were shared by other apophatic mystics of the period, such as Marguerite Porete (d. 1310 CE), who echoed these themes.

Lichtmann (1994) points out the similarity between Eckhart and Porete concerning abegescheidenheit. Eckhart's abegescheidenheit, like Porete's aneantissement, or annihilation, relentlessly purifies the soul of attachment to works, to the will of God, or to heavenly reward. Yet, where Eckhart has an abegescheidenheit that is literally a cutting away, Porete has an aneantissement, a gradual 'becoming what one is most deeply' (Lichtmann 1994:84). For both Porete and Eckhart, the apophatic approach facilitates becoming what one is most deeply. There is a mistaken notion that the more quiet apophatic approach makes one remote and distant. The apophatic approach is not at all contrary to human passion. Eckhart writes:

Our upright people, however, say that we must become so perfect that no kind of joy can move us any longer that we must be immoveable to joy or sorrow. They are wrong in this matter. But I say that there was never a saint so great that he or she could not be moved ... This was not the case even for Christ. He let us know this when he said: 'My soul is grieved to the point of death' (Mt. 26:38).

(cited in Fox 2000:484)

For Eckhart, living fully out of the consciousness of truth that is derived from the apophatic approach is more important than memorising dogmas. In that respect, Eckhart is thoroughly contemporary and speaks to the postmodern passion for a living experience over static formula. Berdyaev (1957) put it well when he wrote:

My philosophical thinking does not take a scientific form: it is not ratiocinative, it belongs intuitively to life. Spiritual experience lies at the very foundation of it, and its driving power is a passion for freedom. I do not think discursively. It is not so much that I arrive at truth as that I take my start from it.

(Baerdyaev 1957:v)

For Eckhart, the unconscious landscape is where God's activity takes place. By focusing mysticism within the unconscious landscape, Eckhart and Ignatius, while representing different mystical traditions and psychodynamic movements, nonetheless exemplify that mysticism is an inherent part of the human psyche as it crafts meaning and purpose in life.

Recently, the mystical phenomenon has been studied with respect to the brain; leading researchers such as D'Aquili and Newberg (1999:18) to develop what they refer to as neurotheology. By neurotheology they mean the consideration of the significance and necessity of ritual and myth in terms of the function of the mind/brain and the implications that this analysis has for the formation of specific theologies. This discovery is assisting is deepening the critical dialogue between mysticism and mental health.

\section{NEUROTHEOLOGY}

D'Aquili and Newberg (1999) argue that the neuropsychiatric approach to the mystical experience establishes that there are certain core elements that appear to be universal and that can be separated from particular cultural matrices. From a strictly neuropsychiatric perspective our God consciousness is necessarily interpreted by the brain which gives us our sense of all reality.

Neuroscientists have divided the brain into two main subdivisions. These subdivisions have implications in terms of understanding the neurological basis for the difference between apophatic and kataphatic mystical approaches. Additionally, observation of these hemispheres has given researchers insight into the neurological basis of the 'mystical' mind allowing us to appreciate the fact that mystical experience is a constitutive aspect of our natural human life.

\section{Left/right brain hemispheres and apophatic/ kataphatic mystical approaches}

From research in brain chemistry we know that the main subdivision of the brain is that of the left and right hemisphere. Each hemisphere contains a cerebral cortex, which is generally considered to be the seat of higher-level cognitive functions, as well as sensory and motor control. The left cerebral cortex receives and analyses sensation from, and generates movement in, the right side of the body and the right cerebral cortex receives and analyses sensation from, and generates movement in, the left side. The classic teaching is that the left hemisphere is more involved with analytical and mathematical processes, as well as the time sequential and rhythmical aspects of consciousness. The left hemisphere is also the usual site of the language center, the part of the brain that understands and produces written and oral language (D'Aquili \& Newberg 1999:28).

The right hemisphere is usually more involved with abstract thought distinct from language, non-verbal awareness of the environment, visual-spatial perception and the perception, expression and modulation of most aspects of emotionality (D'Aquili \& Newberg 1999:28). While each of these left and right centres operate independently and can create what appear to be two separate consciousnesses, we also need to see how they work together. In examining the left and right brain hemispheres it is important to realise that each hemisphere has a relationship with the other. For example, even though the major language centre may be in the left hemisphere, the right hemisphere also has an area that concentrates on language. The language area in the right hemisphere comprehends and generates emotional inflection in the language. Thus, the left and right hemisphere work together in such a manner that the left hemisphere can understand what is being said and the right hemisphere can understand how it is being said in terms of emotional nuance (D'Aquili \& Newberg 1999:28). Additionally, the right hemisphere provides the 'space' in which the stimulus from the left is placed. This has relevance for what occurs neurologically with different mystical approaches. 


\section{APOPHATIC MYSTICISM FROM A NEUROLOGICAL PERSPECTIVE}

When deliberate suspension of cognitive activity occurs in apophatic-styled mystical meditation, definite neurological reactions can be observed. In apophatic mysticism, one starts with the intent to clear the mind of thoughts and words. This results in a partial deafferentation of the right orientation association area located in the right hemisphere. 'Deafferentation' is a technical term, which refers to the process whereby incoming information (i.e. afferents) into the brain are 'cut off' (i.e. de-afferented). This cutting off, which is generated through meditative techniques, is an actual physiological process. In apophatic states, there is a deliberate attempt not to pay attention to direct sensory input (D'Aquili \& Newberg 1999:111). The deafferentation of the right orientation association area consists of blocking input from the verbal-conceptual association area, as well as from specific sensory modalities of the left area. Since the right orientation association area is concerned with generating a sense of space in which to orient incoming stimuli, the deafferentation of this orientation (which is the point of apophatic meditation) does not result in unusual visions, sounds or tactile sensations. Hence one rarely hears description of ecstasies reported from apophatic mystics. Instead, the deafferentation that occurs in apophatic mysticism results in an absolute subjective sensation of pure space (D'Aquili \& Newberg 1999:112). At the same instant that the right orientation association area is totally deafferented, the left orientation association area is likewise deafferented. This process results in the obliteration of the self-other dichotomy at precisely the same moment that the deafferentation of the right orientation association area is associated with a sense of absolute transcendent wholeness. D'Aquili and Newberg (1999:112) believe that this results in the subject's attainment of a state of rapturous transcendence and absolute wholeness that conveys such overwhelming power and strength that the subject has the sense of experiencing absolute reality. How this process has been described in mystical language by some Christian apophatic mystics will be described below.

\section{KATAPHATIC MYSTICISM FROM A NEUROLOGICAL PERSPECTIVE}

In kataphatic mysticism, one begins with the subject willing or intending not to clear the mind, but to focus either on a mental image or external physical object. Because the person is calling forth an image from memory, whether a religious symbol or a past memory, and this is affected by the stimulatory impulses running from the right attention association area because, as was stated above, the right hemisphere generates emotional nuance in what is being said or thought. Owing to the fact that attention is focused so intensely on a particular image or memory, there is a corresponding ongoing and powerful stimulation (not deafferenting) coming from the right association area. In this way, the left and right areas are working together. However, in the case of kataphatic mysticism the impulses are facilitatory and stimulating, not inhibiting or deafferenting, as in apophatic mysticism (D'Aquili \& Newberg 1999:114). The result is nonetheless the same; the self-other dichotomy is obliterated during this period of time. However, the feeling is different. It is ecstatic. The person feels absorbed into the object, or is one with the object (D'Aquili \& Newberg 1999:116). How this process has been described in mystical language by some Christian kataphatic mystics will be described below.

\section{GOD CONSCIOUSNESS AND THE}

\section{APOPHATIC AND KATAPHATIC METHOD}

The diverse 'God' consciousness that is produced in apophatic and kataphatic approaches is related to different methodological approaches. Either method leads to differing experiences of what D'Aquili and Newberg (1999:109) describe as 'absolute unitary being'. For example, most mature mystics who practice apophatic mysticism tend to experience a quiescent effect, while those who practice kataphatic mysticism tend to experience an ecstatic effect. In terms of God imaging, the quiescent experience tends to be interpreted impersonally, as the peace and emptiness of the absolute ground of being (the nameless or no-thing God), while in the ecstatic experience, the person feels absorbed into the object of meditation (God is everywhere).

Neuropsychiatric analysis sheds light on why there is a difference in articulation (and consequently a different approach to prayer and meditation) concerning mystical experience, even among mystics of the same religious confession. For example, the apophatic experience lends itself to a certain depersonalisation of the Divine, while the kataphatic experience lends itself to seeing the divine in all things. The apophatic experience described by $\mathrm{D}^{\prime}$ Aquili and Newberg is clearly seen in the apophatic mystic Mechtild of Magdeburg (d. 1279). The kataphatic experience is clearly seen with Ignatius of Loyola. A brief overview of these mystics spiritual experience will serve to illustrate how the mystical mind described neurologically by $\mathrm{D}^{\prime}$ Aquili and Newberg is described in classic religious language.

Mechtild frequently employs the image of the desert in describing her mystical thought. The desert is the landscape of consciousness, which, when emptied, receives the fullness of God. Mechtild (Tobin 1994:49) writes that God whispers to God's beloved within the confines of this desert. It is our clinging to external forms, ideas and multiplicity that keeps us from entering the desert. One lives in the true desert if one loves das niht (nothing) and flees das iht (something). For Mechtild, one must stand alone, not seek consolation, console others, keep busy but be free of all things (Tobin 1994:49). In this way, through the detachment described by Eckhart, the mind experiences a breakthrough, where, 'I am unborn, and following the way of my unborn being I can never die.' The Lord then leads the noble detached mind into a desert and speaks, 'One with one, one of one, one in one, and in one forever' (cited in Tobin 1994:50). The apophatic experience is described by Mechtild as 'sinking', a kind of psychological descent. However this descent does not provoke anxiety or fear. On the contrary, 'the more deeply she sinks - the more sweetly she drinks' (cited in Tobin 1994:51). It is interesting that Mechtild uses the word 'sink' to describe her experience, as this is not ecstatic language.

For Ignatius, the experience is similar, but it culminates in an active, personal and ecstatic apprehension of the Divine in all of creation. Ignatius suggests as a meditation in the fourth and final week of the Spiritual exercises:

The second point is to consider how God dwells in His creatures: in the elements, giving them being; in the plants, giving them life; in the animals, giving them sensation; in men, giving them understanding. So He dwells in me, giving me being, life, sensation, and intelligence, and making a temple of me, since He created me to the likeness and image of His Divine Majesty.

(Gleason 1989:104)

Ignatius suggests that the exercitant think about God as an active worker in the world.

'The ... point' is to consider how God works and labours for me in all created things on the face of the earth, that is, He conducts Himself as one who labours; in the heavens, the elements, plants, fruits, flocks, etc. He gives them being, preserves them, grants them growth, sensation, etc. Then I will reflect on myself.

(Gleason 1989:104)

These differences suggest that diverse methods produce differing orientations. Rohr (1992:226), for example, suggests that apophatic-styled meditation is more natural for the 'gut-centred' types (i.e. people who operate out of sensation and instincts). It is one of the three typologies in the Enneagram (the other two being 'mind-centred' and 'emotional-centred'). Rohr notes that meditation practices in which they are entirely by themselves 
and in their body are best for these people (Rohr 1992:226). The reason for this is because apophatic-styled mysticism will facilitate a space in which to contextualise and calm the raw emotional response to life typical of 'gut-centred' types.

Irrespective of the method, meditation of either type has its benefits. Newberg (2006) refers to academic literature that shows that people who meditate tend to have better mental states, lower levels of depression and anxiety and decreased drug and alcohol abuse. Clearly, opening up the mystical literature of the Christian tradition is a useful means to assist people in their personal integration. Mysticism, in either its kataphatic or apophatic form, does not seek to rupture the person, but to assist in deepening the experience of what it means to be fully human. This process entails a change in perceptual experience; however, that change does not lead to the dissolution of the integrity of the human person. As Merton (1990) writes:

In mystical experience the spirit of the person is indeed aware of the reality of God as 'Other' immanently present within itself, but the more conscious it becomes of His reality and of His 'otherness' the more it [the spirit of the person] also becomes conscious of the union and 'sameness' which unite Him to itself. And this is the great paradox without which mysticism would become schizophrenia, splitting man's [sic] whole personality and destroying him, instead of unifying and integrating and perfecting him in the highest degree.

(Merton 1990:166)

\section{CONCLUSION}

Given the frequency of reported mystical experiences, the scientific exploration of this dimension of human experience is important. While mysticism and mental health practice function in distinct domains, there are significant areas of overlap. Neuropsychiatric research is validating from a neurological perspective the benefits of mysticism for the human person. Additional research concerning the differences between schizophrenia or psychosis and mysticism also helps to clarify the nature of mysticism. Research is pointing to the conclusion that the mystical quest has profound relevance for achieving meaning and purpose in life.

Contemporary research in mysticism illustrates that mystical experience is an integral aspect of the human person and the recovery of the mystical tradition will fill a much-needed void in society. A society that denies the mystical, and lacks a prophetic religion that insists on the primary role of the mystical within the psyche, will fall into various forms of pathological pseudomysticism. Indeed, in our contemporary era, we have seen the ascendancy of various forms of pseudo-mysticism such as nationalism, militarism, fascism, technology, consumerism, fundamentalism, new ageism, asceticism, and psychologism (Fox 1988:46). It is urgent, therefore, that theology find creative ways to offer what is unique in their tradition to the mental health practice. If mysticism does not feed the mind's craving for the mysterious, the wonderful, or the supernatural, then the mind will feed on the garbage of any superstition that it is offered. These superstitions would be false mysticism, though, and would no more discredit the practices of true mysticism, as extolled by Eckhart or Ignatius, than spiritualism discredits spirits or jugglery discredits the miracles of Christ (Tyrrell 1904:26).

This article illuminated the nature of mysticism by describing how, historically, it has been (and continues to be) simultaneously the psychological and spiritual process by which integration and wholeness is achieved. Historically, there has been some reticence within the mental health practice with respect to addressing the mystical dimension of the human person. In recent decades, as new research emerged, we have seen that this is plainly no longer the case. Neuropsychiatry and the social sciences have joined with spirituality in the articulation of mysticism. This dialogue is leading to an emerging consensus with respect to the efficacy of the mystical experience in people's lives and a renewed interest in how these mystical states might be achieved. There are no better guides than the great saints, mystics and Doctors of the Church whose experience has guided people for well over two millennia. Appropriating their insights in a contemporary context is an important contribution in the critical dialogue between mysticism and mental health practice.

\section{REFERENCES}

Allen, C., 1999, 'The holy feminine', First Things 98, 37-44.

Arieti, S., 1976, Creativity: The magic synthesis, Basic Books, New York, NY.

Berdyaev, N., 1957, The beginning and the end, transl. R.M. French, Harper and Brothers Publishers, New York, NY.

Boisen, A., 1936, The exploration of the inner world, University of Pennsylvania Press, Philadelphia, PA.

Bourque, L.B. \& Back, K.W., 1968, 'Values and transcendental experiences', Social Forces 47, 34-38.

Bourque, L.B. \& Back, K.W., 1971, 'Language, society and subjective experience', Sociometry 34, 1-21.

Brown, G.A., Spilka, B. \& Cassidy, S., 1978, 'The structures of mystical experience and pre- and post-lifestyle correlates', unpublished paper presented at the annual meeting of the Society for Scientific Study of Religions, Harford, CT.

Brown, A., 2005, 'The man from whom God hid nothing: An essay on Johannes Eckhart', viewed 14 August 2007, from http://www.philosophos.com/philosophy_article_105.html

Buckley, P., 1981, 'Mystical experience and schizophrenia', Schizophrenia Bulletin 7, 516-521.

Clarke, I., 1998, 'Madness and mysticism: Clarifying the mystery', viewed 05 March 2010, from http://www.scispirit. $\mathrm{com} /$ Psychosis_spirituality/madness_and_mysticism.html

D'Aquili, E. \& Newberg, A., 1999, The mystical mind: Probing the biology of religious experience, Fortress, Minneapolis, IN.

Fleming, D.L. 1978, The spiritual exercises of St. Ignatius: A literal translation and a contemporary reading, The Institute of Jesuit Sources, St. Louis, MO.

Fox, M., 1988, The coming of the cosmic Christ, Harper Collins, San Francisco.

Fox, M., [1980] 2000, Passion for creation - The earth-honoring spirituality of Meister Eckhart, Inner Traditions, Rochester, VT.

Freud, S., [1927] 1961, Future of an illusion: Civilization and its discontents, and other works, Hogarth Press, London.

Gleason, R., 1989, The spiritual exercises of St. Ignatius, transl. A. Mottola, Doubleday, New York, NY.

Greeley, A., 1974, Ecstasy: A way of knowing, Prentice-Hall, Englewood Cliffs, NJ.

Grof, P., 2002, 'The madness of Adam and Eve: How schizophrenia shaped humanity', The Canadian Journal of Psychiatry 47(4), viewed 15 December 2004, from http:// www.cpaapc.org/publication/archives/cjp/3003/may/ bookReviewAdamAndEve.asp

Hay, D. \& Morisy, A., 1978, 'Reports of ecstatic, paranormal, or religious experience', Journal for the Scientific Study of Religion $17,255-268$.

Hood, R., 1973a, 'Forms of religious commitment and intense religious experience', Review of Religious Research 15, 29-36.

Hood, R., 1973b, 'Religious orientation and the experience of transcendence', Journal for the Scientific Study of Religion 12, $441-448$.

Hood, R., 1975, 'The construction and preliminary validation of a measure of reported mystical experience', Journal for the Scientific Study of Religion 14, 29-41.

Hood, R., 1977a, 'Differential triggering of mystical experience as a function of self-actualization', Review of Religious Research 18, 264-270.

Hood, R., 1977b, 'Eliciting mystical states of consciousness with semi-structured nature experiences', Journal for the Scientific Study of Religion 16, 155-163. 
Hood, R., 1978, 'The usefulness of the indiscriminately pro- and anti-religious orientation categories', Journal for the Scientific Study of Religions 17, 419-431.

Hood R., \& Hall J., 1980, 'Gender differences in the description of erotic and mystical experiences', Review of Religious Research 21, 95-207.

Hood R. \& Morris R., 1981, 'Knowledge and experience criteria in the reporting of mystical experience', Review of Religious Research 12(1), 76-84.

James, W., 1961, The varieties of religious experience, Macmillan, New York.

Jaspers, K., [1946] 1963, General psychopathology, transl. J. Hoenig \& M. Hamilton, University of Chicago Press, Chicago, IL.

Karon, B. \& Vandenbos, G., 1981, Psychotherapy of schizophrenia, Jason Aronson, New York, NY.

Laing, R.D., 1967, The politics of experience, Ballantine Books, New York, NY.

Lancaster, B., 2001, 'Eckhart, Kabbalah, and the Limits of Psychological Inquiry', Eckhart Review 10, 39-49.

Leuba, J.H., 1929, Psychology of religious mysticism, Harcourt Brace, Orlando, FL

Lichtmann, M., 1994, 'Marguerite Porete and Meister Eckhart: The mirror for simple souls mirrored', in B. Mcginn (ed.) Meister Eckhart and the Beguine mystics, pp. 65-87, Continuum, New York, NY.

Lukoff, D., 1985, 'The diagnosis of mystical experiences with psychotic features', The Journal of Transpersonal Psychology 17(2), 155-181.

Margolis, R. \& Elifson, K.W., 1979, 'A typology of religious experience', Journal for the Scientific Study of Religion 18, 61-67.

May, R., 1969, Love and will, Norton, New York, NY.

McGinn, B., 2000, The mystical thought of Meister Eckhart: The man from whom God hid nothing, Crossroad, New York, NY.

McGinn B. \& Colledge, E. (eds.), 1981, Meister Eckhart: The essential sermons, commentaries, treatises and defense, Paulist, New York, NY.

Merton, T., [1961] 1990, The new man, The Noonday Press, New York. NY.

Merton, T., [1968] 1989, Conjectures of a guilty bystander, Bantam Doubleday, New York, NY.

Mills, J., 2003, 'Eckhart's standing today', Eckhart Review 13, 60-64.

Newberg, A., 2006, 'Meaning of life TV', Slate, viewed 25 November 2007, from http://meaningoflife.tv/video.php?sp eaker=newberg\&topic $=$ anybodmed

Norris, K., 1996, The cloister walk, The Berkley Publishing Group, New York, MY.
O'Neal, N., 1993, The life of St. Ignatius of Loyola, Fox, Milwaukee, WI.

O'Neal, D., 1996, Meister Eckhart from whom God hid nothing, Shambhala, Boston, MA

Prince, R., 1979, 'Religious experience and psychosis', Altered States of Consciousness 5(2), 167-181.

Ratzinger, J., 1989, 'Letter to the bishops of the Catholic Church on some aspects of Christian meditation', Congregation for the doctrine of the faith, viewed 21 April 2010, from http:// www.ewtn.com/library/curia/cdfmed.htm

Rohr, R., 1992, Discovering the enneagram: An ancient tool, a new spiritual journey, Crossroad, Chestnut Ridge, NY.

Schurmann, R., 2001, Wandering joy: Meister Eckhart's mystical philosophy, Lindsfarne Books, Great Barrington, MA.

Siglag, M., 1986, Schizophrenia and mystical experience: Similarities and differences, University of Detroit Press, Detroit, MI.

Stephens, R., 2005, 'How should we suffer?' Eckhart Review 14, 30-40.

Tobin, F., 1994, 'Mechtild of Magdeburg and Meister Eckhart: Points of comparison', in B. McGinn (ed.), Meister Eckhart and the Beguine Mystics, pp. 44-65, Continuum, New York, NY.

Thomas, L. \& Cooper, P., 1977, 'The mystical experience: Can it be measured by structured questions?', unpublished paper presented at the annual meeting of the American Sociological Association, Chicago, IL

Thomas, L. \& Cooper, P., 1978, 'Measurement and incidence of mystical experience: An exploratory study', Journal for the Scientific Study of Religion 17, 433-37.

Thomas, L. \& Cooper, P., 1980, 'Incidence and psychological correlates of intense spiritual experiences', Journal of Transpersonal Psychology 12(1), 75-85.

Thoreau, H., [1854] 1985, Walden and other writings, Prospero Classics Library, Toronto.

Tobin, F., 1994, 'Mechtild of Magdeburg and Meister Eckhart Points of comparison,' in B. McGinn (ed.), Meister Eckhart and the Beguine mystics, pp. 44-65, Continuum, New York, NY.

Tyrrell, G., 1904, Hard sayings: A selection of meditations and studies, Longmans Green, London.

Woods, R., 2005, 'Eckhart, suffering and healing', Eckhart Review $14,5-29$.

World Health Organization, 1998, WHOQOL and spirituality, religiousness and personal beliefs: Report on WHO consultation, WHO, Geneva.

Wuthnow, R., 1978, Experimentation in American religion, University of California Press, Berkley, CA 